\title{
ASBAB NUZUL \\ (Urgensi dan Fungsinya Dalam Penafsiran Ayat Al-Qur`An)
}

Syukraini Ahmad*

\begin{abstract}
Abstrak
Al-Quran sebagai pedoman dan petunjuk bagi manusia terutama bagi orang yang bertaqwa maka perlu dipahami dan ditafsirkan dengan benar dan tepat. Dalam memahami dan menafsirkannya pengetahuan tentang asbab nuzul ayat dinilai sangat penting, terutama ayat-ayat al-Qur'an yang memiliki sabab nuzul. Ini karena seorang mufassir tidak mungkin mengetahui penafsiran suatu ayat Al-Quran tanpa bersandarkan kepada kisah dan penjelasan sebab turunnya. Sedangkan penjelasan sabab nuzul Al-Quran merupakan cara yang kuat dalam memahami dan menafsirkan makna-makna ayat Al-Quran. Di samping itu, sabab nuzul memiliki banyak fungsi yang utama, diantaranya: Mengetahui hikmah pensyariatan hukum, Mengkhususkan hukum, Memastikan makna ayat AlQur'an dan menghilangkan kerancuan maknanya, Memahami dan memantapkan wahyu dalam benak setiap orang yang mendengarnya.
\end{abstract}

Kata Kunci : Urgensi, Fungsi, Asbab Nuzul

\section{Pendahuluan}

Sebagian orang memang ada yang tidak memandang penting sabab nuzul dalam menafsirkan Al-Qur'an. Tanpa sabab nuzul, kata mereka, tidak ada halangan untuk memahami dan menafsirkan ayat Al-Qur'an tanpa harus melengkapi dirinya dengan ilmu tentang sabab nuzul al-Qur`an karena ia mengalir sebagaimana mengalirnya sejarah. Pandangan ini tentu salah, bahkan sabab nuzul mempunyai banyak faidah. ${ }^{1}$

Mayoritas di kalangan mufassir apa pun madzhab tafsir yang dianut dan metode penafsiran yang digunakan, semuanya mengakui urgensi dan fungsi Sabab nuzul dalam menafsirkan Al-Qur'an. Mengetahui Sabab nuzul bagi mufasir, bukan tidak memiliki arti apa pun, melainkan justru akan lebih memperdalam penghayatan dan wawasan penafsiran Al-Qur'an. Bahkan menyangkut penafsiran ayat-ayat tertentu, sabab nuzul bisa membentengi mufassir dari kemungkinan menghasilkan penafsiran Al-Qur'an yang salah dan berakibat fatal. 


\section{A. Pengertian Asbabun Nuzul}

Kata Asbabun Nuzul terdiri dari kata Asbab dan An-Nuzul. Asbab dapat berarti ） Sل شيء يتصل إلى غيره (sesuatu yang menyampaikan kepada sesuatu yang lain, كل حبل حدرته من الحبل (tali, tambang), dan

فوق2 (tiap tali yang kamu turunkan dari atas) sedangkan an-Nuzul berarti الحلول وقد نزلهم ونزل عليهم ونزل بهم (menempati dan menempati tempat mereka). ${ }^{3}$

Sedangkan secara terminologi ada beberapa pengertian yang diberikan oleh para ulama ulumul Qur`an. Di antaranya:

Az-Zarqaniy menyebutkan:

$$
\text { سبب النزول : ما نزلت الأية أو الايات متحدثة عنه او }
$$

$$
\text { مبينة لحكمه أيام وقوعه }
$$

"Sabab Nuzul ialah sesuatu (yang karena sesuatu itu menyebabkan) turun satu atau beberapa ayat Al-Qur'an yang berbicara tentangnya atau menjelaskan hukumnya disaat sesuatu itu terjadi."4

Manna' Al-Qaththan menyebutkan :

$$
\text { سبب النزول هو ما نزل قرآن بشأنه وقت وقوعه كحادثة }
$$

"Sababun Nuzul ialah sesuatu yang dengan keadaan sesuai itu Al-Qur'an diturunkan pada waktu sesuatu itu terjadi seperti suatu peristiwa atau pertanyaan."5

Berdasarkan dua definisi Asbab Nuzul diatas maka dapatlah diformulasikan bahwa asbab nuzul ialah sesuatu yang karena sesuatu itu menyebabkan satu atau beberapa ayat AlQur'an diturunkan yang berbicara tentangnya atau menjelaskan hukumnya disaat sesuatu itu terjadi. Yang dimaksud dengan sesuatu itu sendiri ada kalanya berbentuk kejadian atau pertanyaan yang diajukan kepada Rasulullah saw.

Adapun ayat yang diturunkan karena suatu peristiwa menurut azZarqaniy ada tiga bentuk.

Pertama, peristiwa khusumah (pertengkaran) yang sedang berlangsung, semisal perselisihan antara kelompok Aus dan Khazraj yang disebabkan oleh propokasi kaum Yahudi sampai mereka berteriak "as-silah, as-silah" yang berarti senjata, senjata. Karena peristiwa ini maka turunlah beberapa ayat dari surat Ali Imran yang dimulai dari ayat 100 :
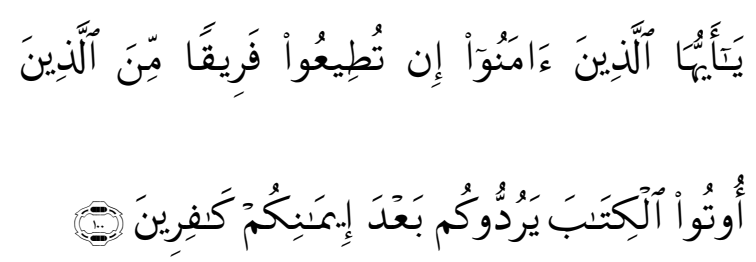

"Hai orang-orang yang beriman, jika kamu mengikuti sebahagian dari orang-orang yang diberi Al Kitab, niscaya mereka akan 
mengembalikan kamu menjadi orang kafir sesudah kamu beriman."

Hingga beberapa ayat berikutnya yang memperingatkan kedua suku ini untuk menghindari dari bercerai berai dan permusuhan dan mengingatkan untuk tetap menjalin kasih sayang, persatuan dan kesatuan.

Kedua, Peristiwa berupa kesalahan yang keji yang dilakukan oleh seseorang. Seperti orang masih mabuk mengimami shalat sehingga ia salah dalam membaca ayat surat al-Kafirun. Setelah membaca surat al-Fatihah lalu dia membaca:

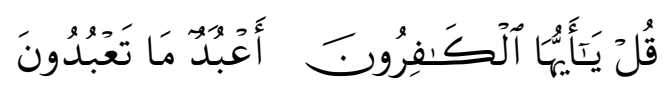

Dia lupa membaca $\bar{\gamma}$ pada kata أَعَبُد yang semestinya لَا أَعَبُد لَّ. Maka turunlah ayat 43 surat an-Nisa:

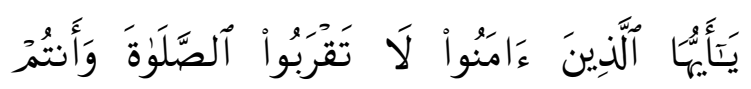
سُكَرَكَ حَتَّى تَعَلَمُواُ مَا تَقُولُونَ

"Hai orang-orang yang beriman, janganlah kamu shalat, sedang kamu dalam Keadaan mabuk, sehingga kamu mengerti apa yang kamu ucapkan."

Ketiga, Peristiwa mengenai cita-cita dan harapan, seperti Muwafaqat (kesesuaian, kecocokan) Umar RA. seperti yang diriwayatkan oleh AL-Bukhari dan lain-lain dari Anas RA berkata bahwa Umar RA telah berkata: "Aku ada kesesuaian dengan Tuhanku dalam tiga perkara. Aku katakan kepada Rasulullah bagaimana kalau maqam Ibrahim kita jadikan sebagai tempat shalat, maka turunlah ayat 125 surat Al-Baqarah:

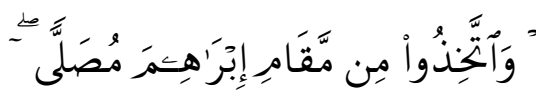

"dan jadikanlah sebahagian maqam Ibrahim tempat shalat."

Dan aku berkata ya Rasulullah: "Sesungguhnya di antara orang-orang yang menemui isteri-isterimu ada yang baik dan adapula yang jahat, bagaimana kalau baginda memerintahkan kepada mereka untuk membuat hijab (tabir), maka turunlah ayat hijab, yakni ayat dari surat al-Ahzab ayat 53.
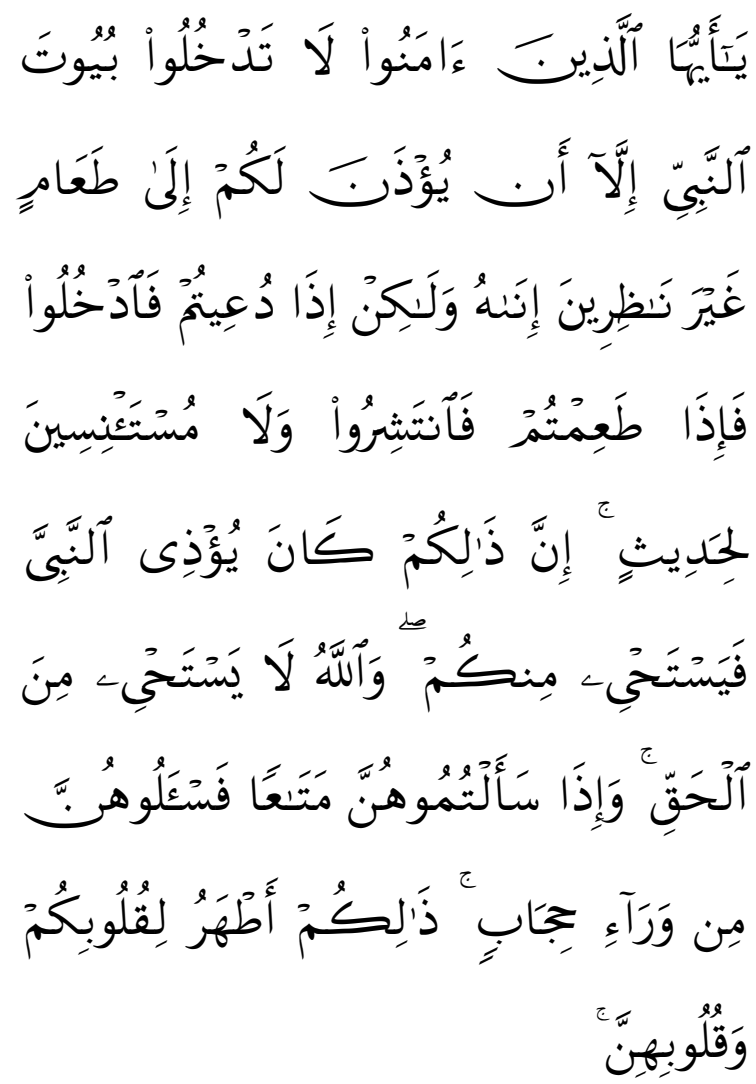
"Hai orang-orang yang beriman, janganlah kamu memasuki rumah- rumah Nabi kecuali bila kamu diizinkan untuk Makan dengan tidak menunggu-nunggu waktu masak (makanannya), tetapi jika kamu diundang Maka masuklah dan bila kamu selesai makan, keluarlah kamu tanpa asyik memperpanjang percakapan. Sesungguhnya yang demikian itu akan mengganggu Nabi lalu Nabi malu kepadamu (untuk menyuruh kamu keluar), dan Allah tidak malu (menerangkan) yang benar. apabila kamu meminta sesuatu (keperluan) kepada mereka (isteri-isteri Nabi), Maka mintalah dari belakang tabir. cara yang demikian itu lebih suci bagi hatimu dan hati mereka."

Dan isteri-isteri Rasulullah saw berkumpul dalam keadaan cemburu lalu Aku (Umar) menegur mereka, lalu turunlah ayat 5 surat at-Tahrim:
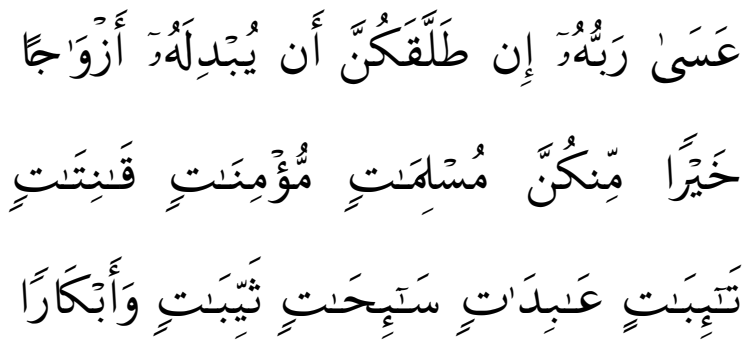

"jika Nabi menceraikan kamu, boleh jadi Tuhannya akan memberi ganti kepadanya dengan isteri yang lebih baik daripada kamu, yang patuh, yang beriman, yang taat, yang bertaubat, yang mengerjakan ibadat, yang berpuasa, yang janda dan yang perawan."6
Sedangkan ayat ataupun beberapa ayat yang diturunkan karena ada pertanyaan yang ditujukan kepada Nabi saw juga ada tiga bentuk, yaitu:

Pertama, Pertanyaan tentang peristiwa masa lampau. Seperti firman Allah SWT dalam surat al-Kahfi ayat 83:

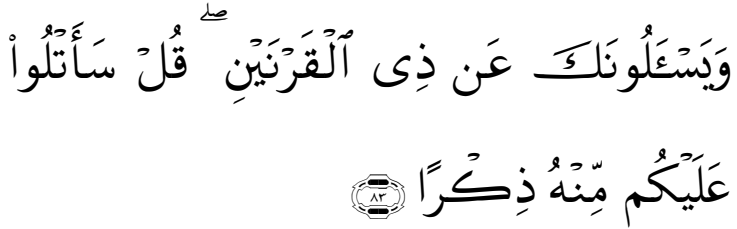

"dan mereka akan bertanya kepadamu (Muhammad) tentang Dzulkarnain. Katakanlah: "Aku akan bacakan kepadamu cerita tentangnya."

Kedua, Pertanyaan tentang peristiwa yang sedang berlangsung. Seperti firman Allah SWT dalam surat alIsra` ayat 85 :

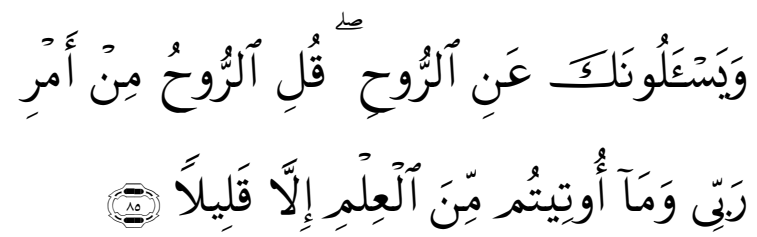

"dan mereka bertanya kepadamu tentang roh. Katakanlah: "Roh itu termasuk urusan Tuhan$k u$, dan tidaklah kamu diberi pengetahuan melainkan sedikit".

Ketiga, Pertanyaan tentang peristiwa yang akan datang. Seperti firman Allah SWT dalam surat an-Nazi at ayat 42 :

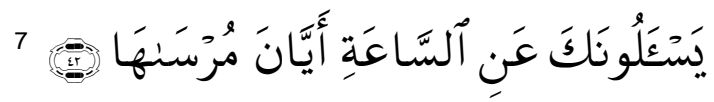


"(orang-orang kafir) bertanya kepadamu (Muhammad) tentang hari kebangkitan, kapankah terjadinya?" 8

أيام “ Menurut az-Zarqaniy, makna "وقوعه adalah waktu diturunkannya ayat al-Quran yang membicarakan tentang sebab tersebut, baik diturunkan langsung sesudah terjadi sebab itu, ataupun kemudian karena memiliki hikmah. Seperti ketika beberapa orang Quraisy bertanya kepada Rasulullah SAW tentang ruh, ashhabul kahfi dan Zulqarnain? Maka Rasulullah SAW mengatakan: besok saya akan memberitahu kalian. Dan beliau tidak mengatakan insya Allah (jika Allah menghendaki) maka wahyupun tidak turun selama 15 hari sebagaimana yang diriwayatkan oleh Ibnu Ishaq, dan ada yang mengatakan 3 hari, dan adapula yang mengatakan 40 hari, sehingga beliaupun merasa gelisah. Kemudian turunlah wahyu yang menjawab pertanyaan-pertanyaan tersebut. Disini terdapat hikmah, Allah ingin membimbing RasulNya tentang adab memujinya dengan ungkapan Insya Allah. Dan Allah berfirman dalam surat al-Kahfi ayat 23-24:

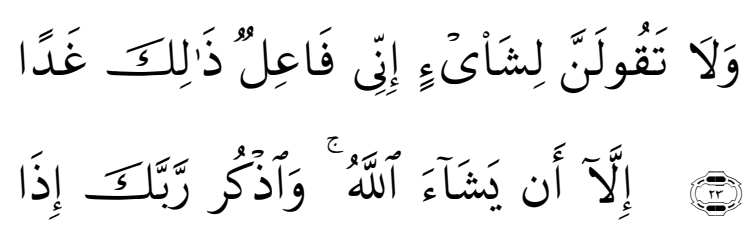

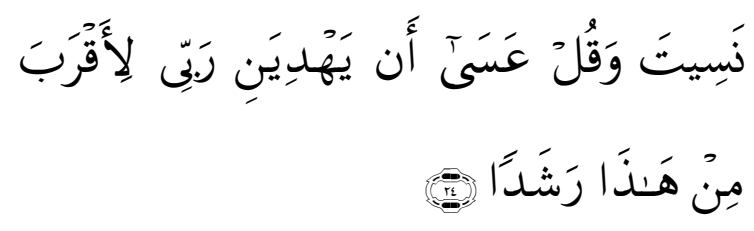

"dan jangan sekali-kali kamu mengatakan tentang sesuatu: "Sesungguhnya aku akan mengerjakan ini besok pagi, kecuali (dengan menyebut): "Insya Allah". dan ingatlah kepada Tuhanmu jika kamu lupa dan Katakanlah: "Mudah-mudahan Tuhanku akan memberiku petunjuk kepada yang lebih dekat kebenarannya dari pada ini".

Az-Zarqaniy juga mengatakan bahwa tidak semua ayat atau beberapa ayat mempunyai asbab an-Nuzul, diantaranya ayat yang berbicara tentang peristiwa atau keadaan masa lampau dan masa yang akan datang. Seperti kisah nabi-nabi dan umat terdahulu dan juga peristiwa tentang as-Sa`ah (kiamat) dan yang berhubungan dengannya. Ayat-ayat seperti ini banyak terdapat dalam alQur`an al-Karim. ${ }^{9}$ Senada dengan azZarqaniy, Syaikh al-Ja bari juga mengatakan bahwa al-Qur`an diturunkan dalam dua bagian. Bagian pertama, alQur`an diturunkan secara ibtida' (tidak terikat dengan sabab nuzul) dan bagian kedua, al-Quran diturunkan berdasarkan peristiwa dan pertanyaan (yang merupakan sabab nuzul) ${ }^{10}$ 


\section{B. Urgensi Sabab Nuzul.}

Az-Zarkasyi seorang ulama AlQur`an menyebutkan bahwa para mufassir memberikan perhatian terhadap Asbab Nuzul dalam kitab-kitab mereka. Di antara para ulama awal yang mengarang kitab Asbab Nuzul adalah Ali bin al-Madini yang merupakan gurunya Al-Bukhari. Dan yang termasyhur kitab yang dikarang oleh al-Wahidi. Lalu beliau (Az-Zarkasyi) menyebutkan telah salah orang yang beranggapan bahwa Asbab Nuzul tidak penting karena mempelajarinya hanya bagaikan mengikuti peristiwa sejarah. Padahal sebenarnya asbab Nuzul memiliki fungsi-fungsi 11 (yang banyak dan utama dalam memahami dan menafsirkan ayat Al-Qur`an).

Urgensi asbabun nuzul dapat pula dipahami antara lain dari komentar para pakar Ulum Al-Qur’an. Diantaranya berkata Al-Wahidi :

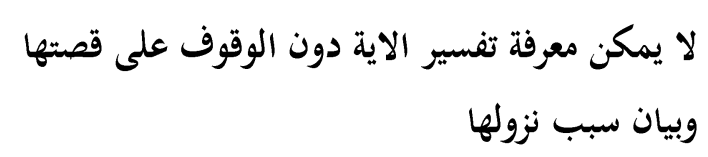

“Tidak mungkin seseorang bisa mengetahui penafsiran suatu ayat Al-Quran tanpa bersandarkan kepada kisah dan penjelasan sebab turunnya."

Ibn Daqiq Al-'Id menyatakan :

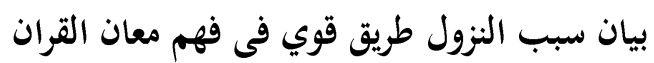

"Penjelasan sabab nuzul merupakan cara yang kuat dalam memahami makna-makna ayat AlQuran."

Kata Ibnu Taymiyah :

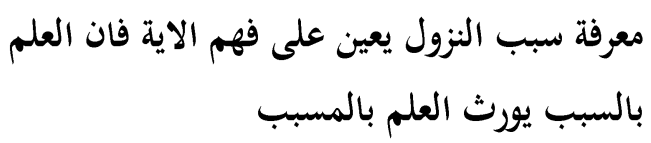

"Mengetahui sabab nuzul membantu seseorang untuk memahami ayat Al-Quran, karena pengetahuan tentang as-sabab (sebab) akan mewariskan pengetahuan terhadap musabbab (akibat)."12

Dari pandangan para ulama ulumul Qur`an di atas maka dapatlah dinilai bahwa mengetahui asbab nuzul sangatlah urgen, karena tidak mungkin dapat memahami dan menafsirkan ayat al-Qur’an dengan benar dan tepat tanpa memiliki pengetahuan tentang sabab nuzul.

\section{Fungsi Sabab Nuzul.}

Ada beberapa fungsi yang dapat diambil dari mengetahui sababun nuzul diantaranya ialah:

1. Mengetahui sisi-sisi positif (hikmah) yang mendorong atas pensyariatan hukum, dan ini bermanfaat bagi orang yang beriman dan orang yang tidak beriman. 
Adapun bagi orang yang beriman maka akan bertambah imannya dan timbul keinginan yang kuat untuk melaksanakan hukum-hukum Allah SWT, dan mengamalkan ayat-ayat al-Qur’an, setelah nampak baginya kemaslahatankemaslahatan dan keistimewaankeistimewaan dari persyariatan hukum Islam dan untuk inilah al-Quran diturunkan. Sedangkan orang kafir maka hikmah-hikmah yang terdapat pada pensyariatan hukum itu akan mengantarkannya kepada beriman, jika ia mau insaf (sadar) ketika dia mengetahui bahwa pensyariatan hukum Islam ini datang untuk menjaga kemaslahatankemaslahatan manusia, bukan untuk menjerumuskannya dan menghukumnya. Sebagai contoh pensyari`atan hukum Islam yang secara bertahap dalam pengharaman khamr. ${ }^{13}$

2. Mengkhususkan hukum bagi siapa yang berpegang dengan kaidah: "bahwasanya ungkapan (teks) Al-quran itu didasarkan atas kekhususan sebab.

3. Kenyataan menunjukkan bahwa adakalanya lafal dalam ayat AlQuran itu bersifat umum, namun membutuhkan pengkhususan yang pengkhususannya itu sendiri justru terletak pada pengetahuan tentang sabab turun ayat itu. ${ }^{14}$

4. Memastikan makna ayat Al-Qur`an 15 dan menghilangkan kerancuan maknanya. 16

Contoh pertama, dalam hadis shahih: dari Marwan bin Hikam bahwasanya dia mengutus seseorang kepada Ibnu Abbas lalu menanyakannya: jika semua orang bahagia dengan nikmat yang ia dapatkan (fariha bima utiya) dan suka dipuji atas apa yang tidak ia lakukan (ahabba an yuhmada bima lam yaf al) akan disiksa sungguh kita semua tentu akan disiksa ? maka Ibnu Abbas menjawab: ayat ini turun tentang ahli kitab. Kemudian beliau membaca ayat 187-188 :
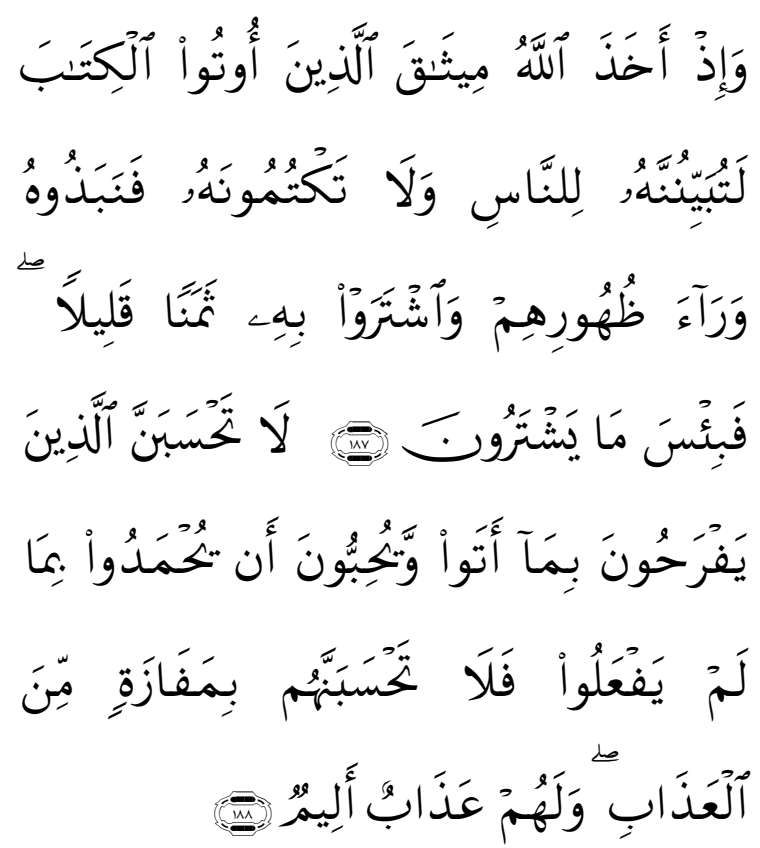
“dan (ingatlah), ketika Allah mengambil janji dari orang-orang yang telah diberi kitab (yaitu): "Hendaklah kamu menerangkan isi kitab itu kepada manusia, dan jangan kamu menyembunyikannya," lalu mereka melemparkan janji itu ke belakang punggung mereka dan mereka menukarnya dengan harga yang sedikit. Amatlah buruknya tukaran yang mereka terima. janganlah sekali-kali kamu menyangka, hahwa orang-orang yang gembira dengan apa yang telah mereka kerjakan dan mereka suka supaya dipuji terhadap perbuatan yang belum mereka kerjakan janganlah kamu menyangka bahwa mereka terlepas dari siksa, dan bagi mereka siksa yang pedih."

Ibnu Abbas mengatakan: "mereka (ahli kitab) ketika ditanya oleh Nabi Muhammad SAW tentang sesuatu lalu mereka menyembunyikannya (jawaban yang sebenarnya), dan mereka mengatakan yang lain. Lalu mereka pergi dengan bangga setelah menjawab yang tidak ditanyakan kepada mereka, mereka bersikap riya dan menginginkan pujian dengan jawaban itu, dan merasa gembira dengan menyembunyikan jawaban sebenarnya. ${ }^{17}$

Contoh kedua, dalam surat al Maidah [5]:93 Allah berfirman:

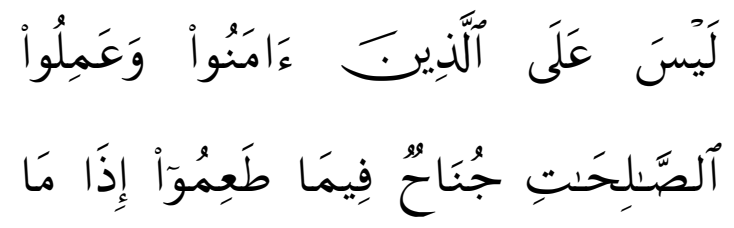

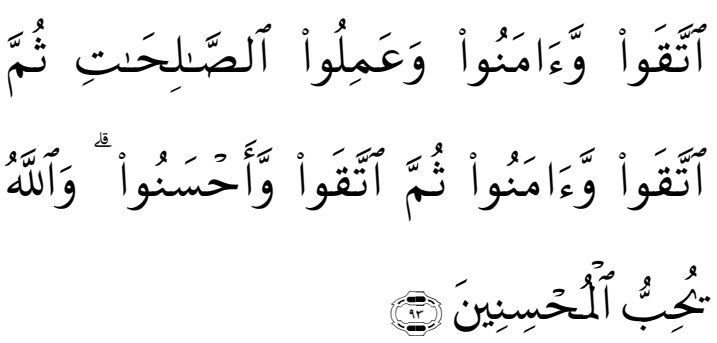

"Tidak ada dosa bagi orang orang beriman dan mengerjakan amalan amalan sholih karena memakan makanan yang telah mereka makan dahulu, apabila (selama itu) mereka tetap bertaqwa serta beriman, dan mengerjakan amalan amalan sholih, kemudian mereka tetap bertaqwa dan beriman, serta kemudian mereka (tetap juga) bertaqwa dan berbuat kebajikan. Dan Allah mencintai orang orang yang berbuat kebajikan."

Secara tekstual, ayat di atas menunjukkan bahwa meminum khamr tidak berdosa selama orang yang bersangkutan tetap beriman dan bertaqwa serta berbuat kebaikan.

Sebagaimana yang diduga oleh Uthman Ibn Maz`un dan `Amr Ibn Ma`di dengan mengatakan bahwa khamr itu boleh berdasarkan pada Al-Qur`an surat al-Maidah ayat 93. Padahal sekiranya mereka berdua mengetahui sabab nuzulnya niscaya mereka tidak akan mengatakan demikian. Sebab nuzulnya adalah ketika turun ayat pengharaman khamr (QS. AlMaidah ayat 90), para sahabat menanyakan, bagaimana nasib mereka yang terbunuh dalam perang fi sabilillah 
(para syuhada') yang sebelum mereka meninggal dunia mereka meminum khamr padahal ia adalah kotoran (rijsun) hukumnya haram? lalu turunlah ayat tersebut.(HR. Ahmad, an-Nasai dan yang lainnya). ${ }^{18}$

Dengan demikian, tidak bisa dikatakan bahwa ayat itu membolehkan lagi minum khamr setelah turun QS. AlMaidah ayat 90 yang secara terangterangan mengharamkan khamr. Kerana yang dimaafkan dalam ayat 93 tersebut adalah perilaku para sahabat yang telah meninggal dunia sebagai syuhada' dan ketika itu khamr belum diharamkan.

Contoh ketiga, Firman Allah SWT:

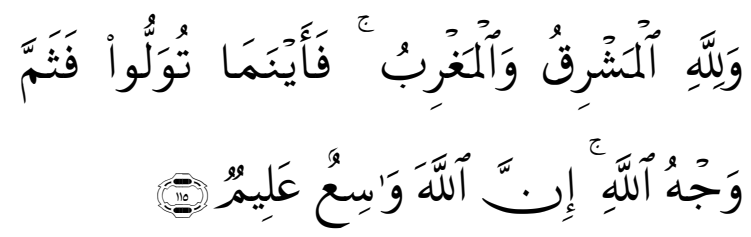

"Dan kepunyaan Allah lah timur dan barat, maka kemanapun kamu menghadap di situlah wajah Allah. Sesungguhnya Allah maha luas (rahmatnya) lagi maha mengetahui (QS al baqarah [2]:115)

Secara tekstual, ayat ini menunjukkan bahwa menghadapkan wajah ke arah manapun di waktu solat itu boleh dan tidak wajib menghadapkan wajah ke arah kiblat baik ketika bepergian maupun tidak bepergian. Dan ini tentu bertentangan dengan ijmak ulama. Akan tetapi, jelas akan menjadi lain pemahaman dan kesimpulannya ketika mengetahui sabab nuzul ayat tersebut. Ayat ini turun bagi orang yang shalat sunnah dalam keadaan bepergian atau pun orang yang shalat namun tidak bisa mengenali arah kiblat yang tepat yakni menghadap ke arah ka'bah baitullah di masjid al Haram lalu dia shalat berdasarkan ijtihadnya namun kemudian ternyata hasil ijtihadnya itu salah. ${ }^{19}$

5. Menghilangkan kerancuan dari pembatasan hukum (dafu tawahhum al-Hashr).

Firman Allah SWT dalam surat alAn`am ayat 145 :
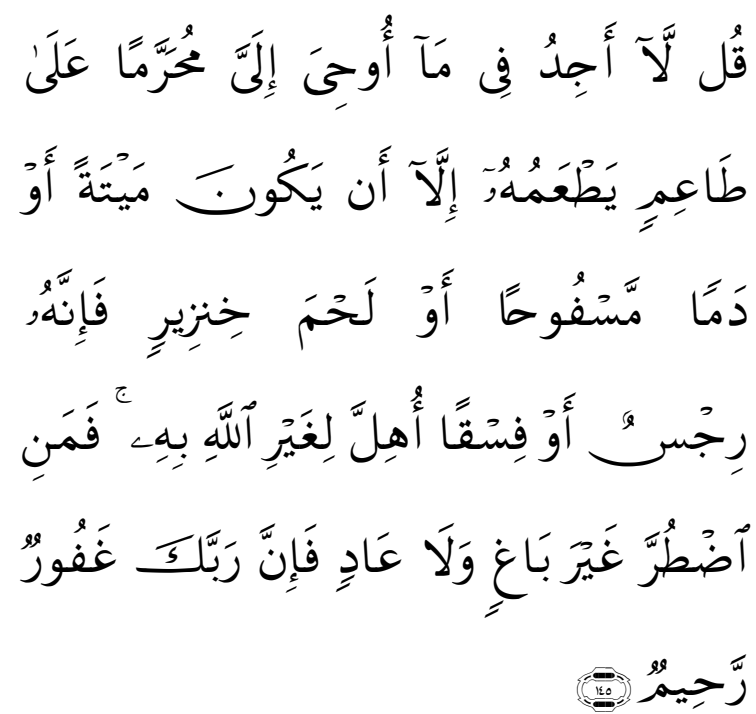

"Katakanlah: "Tiadalah aku peroleh dalam wahyu yang diwahyukan kepadaku, sesuatu yang diharamkan bagi orang yang hendak memakannya, kecuali kalau makanan itu bangkai, atau darah yang mengalir atau 
daging babi - karena sesungguhnya semua itu kotor - atau binatang yang disembelih atas nama selain Allah. Barangsiapa yang dalam keadaan terpaksa, sedang dia tidak menginginkannya dan tidak (pula) melampaui batas, maka sesungguhnya Tuhanmu Maha Pengampun lagi Maha Penyayang".

Dalam ayat tersebut Allah menyebutkan secara eksplisit mengenai keharaman bangkai, darah, daging babi dan binatang yang disembelih karena selain Allah. Ini tidak berarti hanya empat hal ini saja yang diharamkan. Karena jika dilihat sabab Nuzulnya, pembatasan bukanlah tujuan turunnya ayat. Ayat ini turun sebagai reaksi terhadap perilaku orang-orang kafir yang memutar balikkan ketentuan Allah dengan menghalalkan apa yang Allah haramkan dan mengharamkan apa yang Allah halalkan. Sebagaimana Imam Syafi i mengatakan bahwa makna ayat ini adalah orang-orang kafir yang mengharamkan apa yang telah Allah halalkan dan menghalalkan apa yang telah Allah haramkan, ayat ini turun untuk menantang tujuan mereka. ${ }^{20}$

6. Mengetahui suatu ayat diturunkan kepada siapa, sehingga tidak terjadi keraguan yang mengakibatkan penuduhan terhadap orang yang tidak bersalah dan membebaskan tuduhan terhadap orang yang bersalah.
Marwan mengatakan: sesungguhnya dialah (Abdurrahman bin Abu Bakar) orang yang dimaksudkan ayat 17 surat al-Ahqaf :

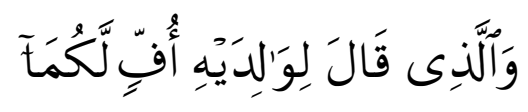

"dan orang yang berkata kepada dua orang ibu bapaknya: "Cis bagi kamu keduanya".

Aisyah menolak tuduhan itu dan menjelaskan sabab Nuzulnya. `Aisyah pun berkata: "Marwan telah berdusta, Demi Allah, bukan dia yang dimaksud dengan ayat itu, kalau seandainya aku ingin menyebutkannya maka aku akan sebutkan siapa namanya" sampai akhir kisah. ${ }^{21}$

7. Memudahkan untuk menghafal, memahami dan memantapkan wahyu dalam benak setiap orang yang mendengarnya, jika ia mengetahui sebab turunnya. Karena hubungan sebab dan akibat, hukum dan peristiwa, peristiwa dan pelaku, masa dan tempatnya, semua itu merupakan faktor-faktor penguat dalam ingatan. ${ }^{22}$

Berdasarkan fungsi-fungsi yang telah diuraikan diatas maka dapatlah dipahami bahwa sabab Nuzul sangatlah urgen diketahui oleh mufassir maupun bagi orang-orang yang hendak memahami makna ayat-ayat al-Qur`an khususnya ayat-ayat yang memiliki sabab nuzul. 


\section{Kesimpulan}

Sabab nuzul ialah sesuatu yang karena sesuatu itu menyebabkan satu atau beberapa ayat Al-Qur'an diturunkan yang berbicara tentangnya atau menjelaskan hukumnya disaat sesuatu itu terjadi. Yang dimaksud dengan sesuatu itu sendiri ada kalanya berbentuk kejadian atau pertanyaan yang diajukan kepada Rasulullah saw.

Sabab Nuzul dinilai memiliki urgensi yang kuat, ini dapat diketahui dari para mufassir yang memberikan perhatian terhadap asbab Nuzul dalam kitab-kitab mereka. Dan banyak ulama yang menyatakan salah orang yang beranggapan bahwa Asbab Nuzul tidak penting karena mempelajarinya hanya bagaikan mengikuti peristiwa sejarah. Padahal sebenarnya asbab Nuzul memiliki fungsi-fungsi yang banyak dan utama dalam menafsirkan ayat Al-Qur`an. Seseorang mufassir tidak mungkin mengetahui penafsiran suatu ayat AlQuran tanpa bersandarkan kepada kisah dan penjelasan sebab turunnya. Sedangkan menjelaskan sabab nuzul AlQuran merupakan cara yang kuat dalam memahami dan menafsirkan maknamakna ayat Al-Quran.

Adapun fungsi-fungsi asbab Nuzul, diantaranya:
1. Mengetahui sisi-sisi positif (hikmah) yang mendorong atas pensyariatan hukum.

2. Mengkhususkan hukum bagi siapa yang berpegang dengan kaidah: "bahwasanya ungkapan (teks) Al-quran itu didasarkan atas kekhususan sebab.

3. Kenyataan menunjukkan bahwa adakalanya lafal dalam ayat Al-Quran itu bersifat umum, namun membutuhkan pengkhususan yang pengkhususannya itu sendiri justru terletak pada pengetahuan tentang sebab turun ayat itu.

4. Memastikan makna ayat Al-Qur’an dan menghilangkan kerancuan maknanya.

5. Menghilangkan kerancuan dari pembatasan hukum (daf u tawahhum alHashr).

6. Mengetahui suatu ayat diturunkan kepada siapa, sehingga tidak terjadi keraguan yang mengakibatkan penuduhan terhadap orang yang tidak bersalah dan membebaskan tuduhan terhadap orang yang bersalah.

Memudahkan untuk menghafal, memahami dan memantapkan wahyu dalam benak setiap orang yang mendengarnya. 


\section{Referensi}

1Jalaluddin Abdurrahan bin Abi Bakr asSuyuthiy, al-Itqan fi Ulum al-Qur'an, Ditashhih dan ditakhrij ayatnya oleh Muhammad Salim Hasyim, Cet.I, (Beirut: Dar al-Kutub al-Ilmiyyah, 2010), hlm.48/ Badruddin Muhammad bin Abdillah azZarkasyiy, al-Burhan fi 'Ulum al-Qur'an, Dita 'iq oleh Mushthofa Abdul Qodir 'Atho, Juz I, (Beirut: Dar alFikr, 1429-1430 H/2009 M), Hlm.45/ Muhammad Abdul Azhim az-Zarqaniy, Manahilul 'Irfan fi 'Ulum al-Qur'an, Ditahqiq oleh Fawwaz Ahmad Zamarli, Juz I, Cet.I, (Beirut: Darul Kitab al-'Arabiy, 1415 H/1995 M), hlm. 91

2Ibnu Manzur, Lisan al-`Arab, Jilid 7 (Beirut: Dar Sadir, t.t.) hlm.100-1001 hlm.237

3Ibnu Manzur, Lisan al-Arab, Jilid 14,

4Muhammad Abdul Azhim az-Zarqaniy, Manahilul 'Irfan fi 'Ulum al-Qur'an, hlm. 89

5Manna' Al-Qathan, Mabahits fi 'ulumil quran, (al-Qohiroh: Maktabah Wahbah, 2000), hlm. 74

6Muhammad Abdul Azhim az-Zarqaniy, Manahilul 'Irfan fi 'Ulum al-Qur'an, hlm. 90

7Ibid.

${ }^{8}$ Kata-kata ini mereka (orang-orang kafir) ucapkan adalah sebagai ejekan saja, bukan karena mereka percaya akan hari berbangkit.

${ }^{9}$ Muhammad Abdul Azhim az-Zarqaniy, Manahilul 'Irfan fi 'Ulum al-Qur`an, hlm.90-91

10Jalaluddin Abdurrahan bin Abi Bakr asSuyuthiy, al-Itqan fi Ulum al-Qur'an, hlm. 48

${ }^{11 B a d r u d d i n ~ M u h a m m a d ~ b i n ~ A b d i l l a h ~ a z-~}$ Zarkasyiy, al-Burhan fi 'Ulum al-Qur'an, hlm. 45

12Jalaluddin Abdurrahan bin Abi Bakr asSuyuthiy, al-Itqan fi Ulum al-Qur'an, hlm.48/ Jalauddin Abdurrahan bin Abi Bakr as-Suyuthiy, Asbabun Nuzul: sebab turunya ayat al-Qur`an, penerjemah Tim Abdul Hayyie, Cet.I, (Jakarta: Gema Insani, 2008), hlm. 11-12/ Muhammad Abdul Azhim az-Zarqaniy, Manahilul 'Irfan fi 'Ulum alQuran, hlm. 91

13Muhammad Abdul Azhim az-Zarqaniy, Manahilul 'Irfan fi 'Ulum al-Qur'an, hlm. 91

${ }^{14}$ Badruddin Muhammad bin Abdillah azZarkasyiy, al-Burhan fi 'Ulum al-Qur'an, hlm. 46/ Jalaluddin Abdurrahan bin Abi Bakr as-Suyuthiy, al-Itqan fi Ulum al-Qur'an, hlm.48

${ }^{15}$ Badruddin Muhammad bin Abdillah az-

Zarkasyiy, al-Burhan fi 'Ulum al-Qur'an, hlm.45

16Badruddin Muhammad bin Abdillah azZarkasyiy, al-Burhan fi 'Ulum al-Qur'an, hlm. 50/ Jalaluddin Abdurrahan bin Abi Bakr as-Suyuthiy, al-Itqan fi Ulum al-Qur'an, hlm. 48

17Badruddin Muhammad bin Abdillah azZarkasyiy, al-Burhan fi 'Ulum al-Qur`an, hlm. 50-51/ Jalaluddin Abdurrahan bin Abi Bakr as-Suyuthiy, al-Itqan fi Ulum al-Qur'an, hlm.48-49/ Subhi As-
Shalih, Membahas Ilmu-ilmu Al-Qur'an, Penerjemah Tim Pustaka Firdaus, Cet.10 (Jakarta: Pustaka Firdaus, 2008), hlm.170-171

18Jalaluddin Abdurrahan bin Abi Bakr asSuyuthiy, al-Itgan fi Ulum al-Qur'an, hlm.49/ Badruddin Muhammad bin Abdillah az-Zarkasyiy, al-Burhan fi 'Ulum al-Qur'an, hlm. 51-52/ Subhi AsShalih, Membahas Ilmu-ilmu Al-Qur'an, hlm.171-172.

19Jalaluddin Abdurrahan bin Abi Bakr asSuyuthiy, al-Itqan fi Ulum al-Qur'an, hlm.49/ Muhammad Abdul Azhim az-Zarqaniy, Manahilul 'Irfan fi 'Ulum al-Qur'an, hlm. 91-92

${ }^{20}$ Badruddin Muhammad bin Abdillah azZarkasyiy, al-Burhan fi 'Ulum al-Qur'an, hlm. 46-47/ Jalaluddin Abdurrahan bin Abi Bakr as-Suyuthiy, al-Itqan fi Ulum al-Qur'an, hlm.49

21Manna' Al-Qathan, Mabahits fi 'ulumil quran, (al-Qohiroh: Maktabah Wahbah, 2000), hlm. 78/ Jalaluddin Abdurrahan bin Abi Bakr as-Suyuthiy, al-Itqan fi Ulum al-Qur'an, hlm.49

22Muhammad Abdul Azhim az-Zarqaniy, Manahilul 'Irfan fi 'Ulum al-Qur`an, hlm.95 